\title{
The Effect of Exercise Methods on Passing Capability of Football Club Players of Padang
}

\author{
Muhammad Qadavi*, Randa Eka Putra \\ Sport Education Program \\ Faculty of Sport Science \\ Padang State University \\ Padang, Indonesia \\ qadavifour@gmail.com
}

\author{
John Arwandi \\ Sport Coaching Education Program \\ Faculty of Sport Science \\ Padang State University \\ Padang, Indonesia
}

\begin{abstract}
This study aims to see if there is any influence of the training series method on the ability passing of SSB Putra Wijaya Padang soccer players. This type of research is a quasi-experiment conducted at the Kompi A Lapai Padang field starting from July 4 to August 3, 2018. The population in this study were 108 SSB Putra Wijaya Padang players. Sampling using a purposive sampling technique with a sample size of 20 U-15 people. Short Passing Test does data retrieval. The test consists of a pre-test first, then treated $\mathbf{1 6}$ times using a series of training methods and ending with a post-test. Data analysis and research hypothesis testing using a t-test with a significant level of $\alpha=0.05$. From the results of data analysis, the value of $t_{0}=13.71$ and $t_{\text {table }}=2.09$. Thus $\left(t_{0}=13.71>t_{\text {table }}=2.09\right)$, then the hypothesis proposed in this study is accepted; namely, there is an influence on the training series method on the ability passing of SSB Putra Wijaya Padang soccer player.
\end{abstract}

Keywords-Exercise, passing, football

\section{INTRODUCTION}

Football is one of the sports in the world that has been popular and has been much in demand by the public. This game has developed into a sport that is popular with all levels of society, from children to parents, both men and women, urban communities to rural communities. This is proven by the number of football clubs and football schools (SSB) which are scattered throughout the country with various forms of expected goals.

One form of government attention in developing achievement sports in Indonesia has been spelled out in [1] concerning the National Sports System, in article 20 paragraphs 2 and 3 explains that: Performance sports are carried out by everyone who has the ability and potential talent to achieve achievement. Achievement sports are carried out through coaching and development in a planned, tiered and sustainable manner with the support of sports science and technology [2].

From the description above it can be seen that the achievements of Indonesian soccer must be supported by coaching and development in a planned, tiered and sustainable manner with the support of sports science and technology. In addition, talent skills and potential are needed to achieve achievement.

In order to become a reliable soccer player at this time, many things need to be considered by the coach or the coach and the player himself in achieving good football achievements. Besides that regular, directed and continuous coaching should be directed at sports performance components such as physical, technical, tactic and mental conditions. One of them can be done and taken through a scientific approach. As for [3] argues that "basically sports performance is determined by four factors namely: (1) physical condition, (2) technique, (3) tactics, (4) mental or psychological". And Ehlenz/Grosser/Zimmermann in [3] made it clear that the physical, technical, tactic and mental conditions are referred to as elements or components of sports prestige because the achievements displayed / exhibited by athletes, both individually and in groups in a match are a combination of physical abilities, techniques, tactics and mental abilities possessed by athletes.

In football games aside from having good physical, tactic and mental conditions, good technical mastery is also needed. Because without good technical mastery, a soccer player cannot achieve the aspirations. The basic techniques in soccer include the technique of carrying the ball (dribling), the technique of passing the ball (passing), the technique of stopping the ball (control), the technique of heading the ball (heading), the technique of kicking (shooting). One of them is passing, passing is the art of making it easy to guide the ball from one player to another. Passing is best done using the feet, but by using other body parts can also pass [4].

To get good passing skills requires good physical conditions, good quality trainers, complete facilities and infrastructure, psychological, intelligent intelligence, and the training methods used. In addition, the selection of appropriate and suitable training models and strategies is needed. The training model is made to fit the player and match the target to be achieved. Furthermore, the trainer must have the knowledge and skills to respond to events that were discovered during the training process.

Putra Wijaya Padang Soccer School, which is training in the Lapai Padang Company Kompi who has dreams and hopes to create professional footballers to achieve achievements ranging from the regional level to the national level. Although the Putra Wijaya Padang Soccer School has not been able to get maximum achievements in the city of Padang from the many friendly matches and official competitions that have been followed so far. Even though the training program that has been created by the trainer has been carried out in accordance with what is given, the game improvement has not been felt much. This can be seen at the time of the 
game, players still often make a fundamental mistake that is a mistake in passing or passing the ball is still not good so it needs more given more material.

In an effort to improve passing skills at the Putra Wijaya Padang Soccer School, training has been given to players, but the expected results have not yet been obtained. The slow increase is due to the fact that the training applied so far has not been maximized in improving the passing ability of SSB Putra Wijaya Padang players. According to [5] "Methodical forms of training are usually carried out on elements of the game such as for technical training both separately and in combination"

Based on the explanation above, the authors argue that the use of appropriate training methods is expected to overcome the problem of the slow increase in the passing ability of the Putra Wijaya Padang Soccer School players. In overcoming the problems above, the coach must create an atmosphere of training that activates athletes so that they master passing well. Therefore, the coach needs a training method that can activate the athlete in mastering passing. Thus the training circuit method is expected to be influential in increasing passing ability.

According to [6] "The method is a way or way how to achieve goals correctly and precisely". An activity that is organized and thinks well will be able to achieve the desired goals or objectives by working in a sequence to facilitate the implementation of an activity carried out.

According to [5] "Training Method is a method used to improve the technical elements both separately and combined, where the training process lasts a long time from the beginning to the end of the exercise. To discuss various training methods in physical education and sports in general can be said as the science of delivery methods and ways of giving in sports teaching ".

The training sequence is a series of activities carried out in stages from simple to complex exercises, including warm-up, main training activities, games in small groups, to cooling. The training load will start from light training on the first training day then there is an increase in training load given on the second training day as well as for the next training day the training load will continue to be added until the goals of the training program made by the trainer are achieved and there is an improvement in conditions as well as the technique of the athlete being trained after being given training using the series of training methods. The use of the training circuit method can also help in applying the training concepts provided by a trainer.

According to Dietrich, et al in [7] emphasize more about the series of training approaches, namely the sequence of exercises used in achieving the objectives of the improvement of technical elements either done separately or even done in combination between the interconnected technical elements between one with another. To know that the series starts with an easy activity and ends in a difficult series with a gradual implementation.

\section{RESEARCH METHODOLOGY}

This study uses quasi-experimental research methods. The goal is "to find whether there is an effect of treatment between cause and effect that is comparing between controlled variables (independent variables and dependent variables)"[8]. This research was carried out at the Padang Wijaya Putra Soccer School, located in Kompi A Field Lapai Padang. Implementation of the initial test on July 4, 2018, conducting treatment on July 6 to August 1, 2018 and the implementation of the final test on August 3, 2018.

The population in this study were all 108 registered members of the Putra Wijaya Padang Soccer School. Based on the opinion above that the population in this study is quite a lot, the sample is taken based on a purposive sampling technique that is in accordance with the criteria desired by the researcher. Then the sample in this study is the soccer player SSB Putra Wijaya Padang, amounting to 20 people who are 15 years old.

The instrument used in this study was the AFC Short Passing Test, Festival of Football Test [9]. Data Analysis Techniques that will be used to test this hypothesis are through techniques that are appropriate to the type and purpose of the study, which will be analyzed using inferential statistics. , t-test formula with a significant level of $5 \%$ to see the difference in the mean, the formula to be used is :

$$
\begin{aligned}
& \mathrm{t}=\frac{\left.\left\lfloor\overline{X_{1}}-\overline{X_{2}}\right\rfloor\right]}{\sqrt{\frac{\sum D^{2}-\left(\sum \frac{D^{2}}{n}\right)}{n(n-1)}}} \\
& \text { Keterangan : } \\
& \overline{X_{1}}=\text { Mean initial test } \\
& X_{2}=\text { final test } \\
& \mathrm{D}=\text { The difference between sample } \\
& \text { scores I and II } \\
& \mathrm{D}^{2}=\text { Different squares } \\
& \sum D^{2}=\text { Number of squares of different powers } \\
& \text { dua } \\
& \mathrm{n} \quad=\text { Number of Samples } \\
& \alpha \quad=0,05
\end{aligned}
$$

\section{RESULTS}

\section{A. Data Description}

Before the treatment of the sample is given with a series of training methods conducted an initial short passing test ability. In the initial test 20 samples obtained the highest score of 22 , the lowest score of 13 , the average score 17.25 and standard deviations 2.4. Then the results of the post-test after being treated for 16 meetings with the ran method description of the training data obtained the highest score of 25 , the lowest score of 17 , an average score of 21.05 and a standard deviation of 2.01. A 
description of each of the overall data in the group can be seen in the following table :

Table 1. Exercise using the exercise circuit method

\begin{tabular}{|c|c|c|c|c|c|}
\hline Data & Samples & Average & Sd & Min & Max \\
\hline Pre test & 20 & 17.25 & 2.403 & 13 & 22 \\
\hline Post test & 20 & 21.05 & 2.012 & 17 & 25 \\
\hline
\end{tabular}

In accordance with the research objectives, the research data are described through the frequency distribution table and histogram. The following will be explained about the description of the form of tests carried out during the initial initial test results and final test results.

\section{Pre Test}

The passing ability variable is measured by using a short passing test. The results of these measurements from 20 samples obtained the highest score of 22 and the lowest score of 13 . The distribution of scores produced an average (mean) of 17.25 and the standard deviation was 2.4. The frequency distribution of pre-test results can be seen in the table below :

Table 2. Pre Test

\begin{tabular}{|c|c|c|}
\hline \multirow{2}{*}{ Class Interval } & \multicolumn{2}{|c|}{ Frequency } \\
\cline { 2 - 3 } & Absolute & Relative(\%) \\
\hline $13-14.8$ & 3 & 15 \\
\hline $14.9-16.7$ & 4 & 20 \\
\hline $16.8-18.6$ & 8 & 40 \\
\hline $18.7-20.5$ & 3 & 15 \\
\hline $20.6-22.4$ & 2 & 10 \\
\hline Total & 20 & $100 \%$ \\
\hline
\end{tabular}

Based on the calculations listed in the above table it can be seen that: 3 people or $(15 \%)$ are in the score group 13$14.8,4$ people or $(20 \%)$ are in the score group of 14.9 $16.7,8$ people or $(40 \%)$ are in the group 16.8-18.6, 3 people or $(15 \%)$ were in the group $18.7-20.5,2$ people or (10\%) were in the group 20.6-22.4.

\section{Pos Test}

Based on the calculations listed in the above table it can be seen that: 3 people or (15\%) are in the score group 13 $14.8,4$ people or $(20 \%)$ are in the score group of 14.9 $16.7,8$ people or $(40 \%)$ are in the group 16.8-18.6, 3 people or $(15 \%)$ were in the group 18.7-20.5, 2 people or $(10 \%)$ were in the group 20.6-22.4. For more details, the pre test frequency distribution can also be seen in the histogram below :

Table 3. Post Test

\begin{tabular}{|c|c|c|}
\hline \multirow{2}{*}{ Class Interval } & \multicolumn{2}{|c|}{ Frequency } \\
\cline { 2 - 3 } & Absolute & Relative(\%) \\
\hline $17-18.6$ & 2 & 10 \\
\hline $18.7-20.3$ & 5 & 25 \\
\hline
\end{tabular}

\begin{tabular}{|c|c|c|}
\hline $20.4-22$ & 9 & 45 \\
\hline $21.1-23.7$ & 2 & 10 \\
\hline $23.8-4.4$ & 2 & 10 \\
\hline Total & 20 & $100 \%$ \\
\hline
\end{tabular}

Based on the calculations listed in the above table it can be seen that: 2 people or (10\%) are in the score group 17-18.6, 5 people or $(25 \%)$ are in the score group 18.7-20.3, 9 people or $(45 \%)$ are in the group $20.4-22,2$ people or $(10 \%)$ were in the group $22.1-23.7,2$ people or $(10 \%)$ were in the group 23.8-24.4.

\section{B. Testing Requirements Analysis}

The hypothesis of this study was tested using t-test analysis. Before the t-test analysis is performed, it will first be tested normality. Testing for normality as follows

\section{Normality test}

After obtaining the pre-test data and post-test data, before the hypothesis test is performed, then an analysis is performed with the liliefors normality test statistic with a significant level that is used as a basis for rejecting or accepting normal decisions whether or not a data distribution is $=0.05$. compare $\mathrm{L}_{\mathrm{O}}$ with Ltable using the criteria: if $\mathrm{L}_{\mathrm{O}}$ is greater than Ltable ( $\mathrm{L}_{\mathrm{O}}>\mathrm{L}_{\text {table }}$ ) means the population is not normally distributed, conversely if Lo is smaller than Ltable (Lo $<\mathrm{L}_{\text {table }}$ ) means the population is normally distributed.

Table 4. Normality Test

\begin{tabular}{|c|c|c|c|c|}
\hline Data & $\mathrm{N}$ & Lo & $\mathrm{L}_{\text {table }}$ & Distribution \\
\hline Pre test & 20 & 0.127 & 0.190 & Normal \\
\hline Post test & 20 & 0.118 & 0.190 & Normal \\
\hline
\end{tabular}

From the table above it is found that all data obtained is spread normally. This indicates that the data can be continued with the hypothesis test (t-test).

\section{Hypothesis testing}

The hypothesis proposed in this study is that there is a significant influence of the training circuit method on the passing ability of the SSB soccer player Putra Wijaya padang. Based on the comparison analysis with the mean different test formula ( $t$ test), the results of the analysis of mean different test ( $\mathrm{t}$ test) are obtained as follows.

\section{Summary Table of the results of hypothesis testing}

\section{Table 5. Results of Hypothesis Testing}

\begin{tabular}{|l|c|c|}
\hline \multicolumn{1}{|c|}{ Hipothesis } & $\mathbf{t}_{\text {count }}$ & $\mathbf{t}_{\text {table }}$ \\
\hline $\begin{array}{l}\text { There is the influence of the training } \\
\text { circuit method on the passing ability of }\end{array}$ & 13.71 & 2.09 \\
$\begin{array}{l}\text { SSB Putra Wijaya Padang soccer } \\
\text { player. }\end{array}$ & & \\
\hline
\end{tabular}

By looking at the table above obtained tcount (13.71)> ttable (2.09) at a significant level $=0.05$, it can be concluded that the hypothesis proposed in this study is accepted, that there is an influence of the training circuit method on the passing ability of Putra Wijaya football players. 


\section{DISCUSSION}

From the hypothesis which states that there is a significant influence between the training circuit method on the passing ability of the SSB player Putra Wijaya Padang. This can be seen from the average increase in scores in the initial and final tests. The average improvement in the ability to make passes with a short pass test with an initial test of 17.25 increased to 21.05 (increased 3.8). based on the results of the calculation of the initial test data and the final test using t-test statistics, the training circuit method has a significant influence on passing ability. This is proven by t-test after t-test obtained thitung $=13.71$ while ttable $=2.09$ with a significant level $\alpha=0.05$ and $n=20$, then tcount $>$ ttable $(13.71>2.09)$. In other words the research hypothesis submitted is accepted (significant).

Based on these findings it can be concluded that there is a significant influence of the training circuit method on increasing passing ability. That by using the training circuit method can be applied in studying the passing ability of football.

training circuit method is a method used in carrying out the exercise process repeatedly based on the level from easy to difficult level. According to Dietrich, et al in [7] emphasize more about the series of training approaches, namely the sequence of exercises used in achieving the objectives of improving the ability of technical elements both separately and in combination between elements of intermittent techniques related to each other. other. To know that the series starts with an easy activity and ends in a difficult series with a gradual implementation. Therefore, the training circuit method is very good for improving one's passing ability, this is in accordance with the results of research in which there is a significant influence between the training circuit method on improving soccer passing ability.

To achieve the best performance, one needs to go through a long training process that is programmed, systematic, directed and continuous in accordance with the sport. The training process is a series of physical and psychological (mental) activities carried out by athletes under the guidance of a coach for the purpose of increasing and maintaining athlete performance. So, by practicing Latiham by using a series of continuous training methods will increase your passing ability.

However, to get the maximum passing ability is not only determined by the right method of training alone, but also supported by one's motivation to undergo the training process with discipline. The choice of training methods and the right form of training cannot be guaranteed to guarantee the success of a coach to improve the passing of his players without the high motivation of someone to follow and undergo the training process with full commitment. From the description above it can be concluded that by using a series of continuous training methods it can improve passing ability, because by using this method players who are not able to pass well will be able to do the technique well and are supported by high motivation from within a person. In addition, there are still influencing factors such as: facilities and infrastructure which also determine success in conducting training. This factor also cannot be ignored in an effort to increase passing ability

\section{CONCLUSION}

Based on the results of the data analysis and discussion, it can be concluded: There is a significant influence of the training circuit method on the passing ability of the SSB soccer player Putra Wijaya Padang. With tcount $>$ ttable (13.71> 2.09). this means an increase in passing ability test results using the Short Passing Test with practice using the training circuit method. this is evidenced by the increase in the average initial test 17.25 increased to 21.05

\section{REFERENCES}

[1] Undang-Undang Negara Republik Indonesia No.3 tahun 2005. Sistem Keolahragaan Nasional. Jakarta. Fokusmedia. 2005, pp. 34.

[2] E. Abus. "Buku Ajar Sepakbola". Padang: FIK UNP. 2005 , pp. 36.

[3] Syafruddin. "Ilmu Kepelatihan Olahraga Teori dan Aplikasinya dalam Pembinaan Olahraga". Padang: Fakultas Ilmu Keolahragaan Universitas Negeri Padang. 2011, pp. 89.

[4] D. Mielke. "Dasar-Dasar Sepakbola". Bandung: Pakar Raya. 2003, pp. 51.

[5] R. Darwis. "Sepakbola". Padang: Universitas Negeri Padang. 1999, pp. 12.

[6] Syafruddin. "Pengantar Ilmu Melatih". Padang: FPOK IKIP. 1999, pp. 55.

[7] Z. Djezed. Dkk. "Buku Pembelajaran Sepakbola". Padang: FPOK IKIP. 1985, pp. 25.

[8] Sugiyono. "Metode Penelitian Kuantitatif dan Kualitatif dan R\&D”. Bandung: Alfabeta. 2010, pp. 87.

[9] AFC. "Grassroots Handbook AFC Coaching Guide for Boys \& Girls Aged 6-12”. Kuala Lumpur: AFC. 2006, pp. 41 . 